\title{
REE enrichment in the karst bauxites of Sierra de Bahoruco (Dominican Republic)
}

CRISTINA VILLANOVA-DE-BENAVENT ${ }^{1}$, JOAQUÍN A. PROENZA $^{1}$, THOMAS AIGLSPERGER ${ }^{2}$, LISARD TORRO $\mathrm{ABAT}^{3}, \mathrm{CRISTINA} \mathrm{DOMÈNECH}^{4}$, JESÚS RODRÍGUEZ ${ }^{5}$, AUSTRALIA RAMÍREZ ${ }^{5}$ AND BERNHARD DOLD ${ }^{6,7}$

${ }^{1}$ Universitat de Barcelona

${ }^{2}$ Luleå University of Technology

${ }^{3}$ Pontifical Catholic University of Peru

${ }^{4}$ University of Barcelona

${ }^{5}$ Servicio Geológico Nacional

${ }^{6}$ Pontificia Universidad Católica del Perú

${ }^{7}$ SUMIRCO. EIRL; RUT

Presenting Author: cvillanovadb@ub.edu

Karst bauxites from Sierra de Bahoruco (SW Dominican Republic) are classified as Fe-rich with a high degree of laterisation. Bauxite samples are composed primarily of gibbsite and contain minor proportions of hematite, boehmite, Algoethite, Fe-Mn oxyhydroxides (asbolane), Ti oxides, zircon, apatite, quartz, calcite, and $\mathrm{Cr}$-spinel; some samples contain kaolinite. All the studied deposits yield high REE contents (average $\sum \mathrm{REE} \sim 1,900 \mathrm{ppm}, \sum \mathrm{REY} \sim 3,066 \mathrm{ppm}$; maximum $\sum$ REE $\sim 14,000$ ppm, $\sum$ REY $\sim 29,000$ ppm). REE contents are positively correlated with $\mathrm{MnO}, \mathrm{P}_{2} \mathrm{O}_{5}, \mathrm{Ni}, \mathrm{Co}$, and $\mathrm{Cu}$. They are also rich in other critical metals like $\mathrm{Sc}, \mathrm{Ga}, \mathrm{V}, \mathrm{Ti}, \mathrm{Zr}$ and $\mathrm{Nb}$.

Most deposits are enriched in LREE (La, Ce, Nd), while a few are enriched in HREE (Y, Gd, Dy). Chondrite-normalised REE patterns show two different trends: a) enriched 50-1200 times, with negative slopes between LREE and MREE and flat segments between MREE and HREE; b) enriched 800-10,000 times, with negative $\mathrm{Ce}$ anomalies, slight positive slopes for LREE and flat MREE-HREE segments. The identified REEbearing minerals include primary (LREE-monazite) and secondary (Y, Gd, Dy, Sm, Yb-rhabdophane, churchite, and florencite) phosphates, carbonates ( $\mathrm{Gd}, \mathrm{Nd}, \mathrm{Sm}$-bastnäsite and tengerite), and oxyhydroxides.

Geochemical stability plots reveal that dominant REE solid phase depends on the total concentration of carbonate and/or phosphate in the solution. Phosphates are the most stable solid phases for $\mathrm{Nd}, \mathrm{Gd}$ and $\mathrm{Sm}$, at $\left[\mathrm{CO}_{3}{ }^{2-}\right]_{\text {total }} /\left[\mathrm{PO}_{4}{ }^{3-}\right]_{\text {total }} \leq 2$, while carbonates and hydroxide solid phases are clearly the dominant ones when total aqueous carbonate concentration is two orders of magnitude higher than that of phosphate. Carbonates appear at circumneutral $\mathrm{pH}$, whereas hydroxides are stable at more alkaline $\mathrm{pH}$. 